\title{
Approaching Hysteria through an Irigararian Perspective in Fay Weldon's Praxis
}

\author{
Omar Mohammed Abdullah, PhD Student \\ Universiti Putra Malaysia
}

doi: 10.19044/esj.2016.v12n11p341 URL:http://dx.doi.org/10.19044/esj.2016.v12n11p341

\begin{abstract}
Hysteria is read as 'the female malady', a disease or sickness women suffer from. This reading could be one among other such readings that construe hysteria as a transgressive force by which women achieve or regain some lost desire. Luce Irigaray considers hysteria as a non-verbal language employed as a form of protest against patriarchal law which is instrumental in bequeathing hysteric symptoms to women. Constant fear, disturbed sleep, marginalization, trauma ... etc., are products of patriarchy which manifest in women. The heroine in Fay Weldon's Praxis also suffers similar symptoms. Irigaray's reading of hysteria with sub-concepts of Mimicry and Masquerade will help to explore and reveal hysteria as a transgressive means by which women fight for their existence and attain their desires. This reading is applied to Weldon's novel to reveal how the protagonist managed to construct an identity she strived for through hysteria.
\end{abstract}

Keywords: Hysteria, Irigaray, Masquerade, Mimicry, Subjectivity, Praxis

\section{Introduction}

Fay Weldon's popularity comes from her comic and playful style which captures critics' attention. More elaborately, Allen Massie in judging the British novel from 1970 to 1989 confirms that Weldon's clarity and "ruthlessness of vision" in her novels of the seventies embody the sharpest statement of feminist stand in British fiction (1990, 38). Her novels mostly deal with subjects of infidelity, marriage, sexual initiation, divorce, motherhood, housework (Krouse 1978,5 ) She tries hard to find ways to help her characters; rebel, breakout, revolutionize and renounce the role of the victim in order to find their identity. While doing so, they may resort to hysteria as a weapon and abjection as a remedy to create that long-lost identity.

Weldon states "We women, we beggars, we scrubbers and dusters, we do the best we can for us and ours. We are divided amongst ourselves. 
We have to be, for survival's sake” $(1974,194)$. This statement is taken from one of her early novels, Female Friends. Her strong opinions on women and femininity has compelled me to choose Female Friends simply because it is an earlier publication to Praxis and one which carries themes of women, their suffering and quest for identity, themes which also date back to her first novel, The Fat Woman's Joke in 1967. It is the norm then for such topics to be highlighted and developed in each of Weldon's works. Thus she discusses women's suffering in Praxis and further develops this theme in The She-Devil. This startling portrayal of women is not only a recurrent theme in Female Friends, Praxis or the She-Devil, but also reflects, according to Weldon, the real status of women in society.

Luce Irigaray's perspective on these social evils describes women's suffering as a form of hysteria that cannot be healed unless women are given a space to express themselves and establish femininity uncontrolled by males. As such, Irigaray attributes women’s hysteric symptoms to patriarchy, lost femininity and marginalization.

\section{Irigaray’s Concept of Hysteria}

Irigaray holds that hysteria can be read as the neurosis of the silent woman, the woman who cannot speak because she is suppressed and thus speaks in bodily symptoms mode. According to Irigaray and as witnessed in Praxis, the hysteric woman refuses to be the maternal corporeal and forgets about herself-; this justifies why Praxis leaves everything behind, even her children, in order to establish herself. Praxis, in accordance with Irigaray's perspective, refuses to be a productive body for her boyfriend Willie, her husbands Ivor and later, Philip who are all representatives of patriarchy. In this case, she revolts against the exploitation and appropriation of her body (Irigaray 1985a, 71). Praxis’s hysterical symptoms, based on Irigaray’s ideas, can be read as a form of rebellion against the requirements of femininity, which subjugates her to castration and deep humiliation.

\section{Praxis, a Hysteric Subject}

Praxis' life can be described as hysterical because she grew up in such hysterical circumstances. Having a hysterical mother who suffers from madness confined Praxis to a life of suffering. Moreover, her mother filled her with fear and horror after learning of Praxis's lesbian like crush on her friend Louise Gaynor, from Praxis’s diary. Praxis’s suffering is thus twofold interpersonal instigation by her mother and sister, and societal instigation. Freud had asserted that family can be a significant breeder of hysterical symptoms; when there is a female suffering from hysteria there must be a father, a brother, a son or a husband nearby, who help in making the female subject become a true hysteric but under sexual terms. Irigaray extends on 
Freud's ideology and describes those figures as representatives of patriarchy who objectify and mistreat women. Irigaray underscores the fact that women are subject to constraints and marginalization and holds society accountable for erasing their femininity and desires. The family, as the smallest unit of society is also a culprit, because it works in tandem with society. Praxis' family comprising mother and sister are responsible for Praxis's hysteric symptoms. Lucy, the mother and Hypatia, the sister are true examples of agents of patriarchy. They both target Praxis and turned her childhood from being peaceful and innocent into a traumatic violent one.

Her mother Lucy has suffered violence at the hands of her husband Ben. The narrator portrays how he persecutes his family: "Ben Duveen drunk, laughing and beating his wife" (8). He is the stereotypical representation of male characters portrayed in most fictional works by Weldon and El Saadawi; the male is the agent who wreaks havoc on women's lives and causes them to suffer, whether wives, sisters or daughters. Ben used to target Lucy with his violence: “'frigid bitch,' he seizes her hair, pulls back her head [...] if he wishes to rape her, he could, he would. The little girls [Praxis and Hypatia] fall quiet: terror silences them” (12). Praxis would later reflect on Lucy's traumatic life as her own: "if the mother has been driven into a breakdown by his harshness" (80). This madness consequently is another trait of evil related to women.

Elaine Showalter shows the "pervasive cultural association of women and madness" and refers to how the "statistical over representation of women among the mentally ill" has been attributed to "their social situation, both their confining roles as daughters, wives, and mothers and their mistreatment by a male-dominated and possibly misogynistic psychiatric profession.” Showalter also stresses the fact that women are typically located on the side of irrationality, nature, silence and body, while men are situated on the side of mind, culture, discourse, and reason (1985, 3-4). Praxis's suffering at a personal level first begins from having observed her mother's trauma and later, her own at the hands of her mother and sister, followed by a general level where she is the targeted by society, especially, men.

\section{Hysteria, Society and Praxis}

Praxis's predicament on a public level starts with the onset of menstruation as she struggles against nature itself. Feelings of revulsion against herself, which are succinctly portrayed by Weldon, depict the harsh reality of women's suffering in an uncaring society. Praxis's troubles escalate when she goes to university and becomes a member of society that objectifies women.

University life marked another hysterical epoch when she encounters patriarchy head on. Willie and Philip are male colleagues who exploit her 
sexually. Later, when Willie pursues and objectifies her, she submits herself to him because she sees submission as a natural part of being a woman. In similar manner to Ruth in the She-Devil, Praxis accepts all social expectations and forsakes her identity for Willie and subsequent husbands, but only comes to realize certain truths about women's existence, much later in life. For now, she willingly surrenders to Willie's sexual demands without expecting any pleasure because at that time, women's singular purpose was to please others above self. Weldon stresses this fact and claims that female desire was not only denied, but was even undiscovered (Faulks 1998). This highlights women's ignorance about themselves, their desires and bodies. The narrator points out that:

Praxis' body seemed as much of mystery to her as ever. She bled once a month, regularly, but barely knew why, and she eased to wonder. She neither felt nor investigated the area between her legs and certainly never took up a mirror to look, imagining that an area so soft, private and forbidden was better left alone. (98)

That is until Irma, her friend, "dressed and undressed in front of Praxis ... [she] was relieved to find that other girls too had a triangle of hair where their legs started" (98). This ignorance of their own bodies leads women to be objectified easily, that is why Weldon calls for a consciousness in women, for them to first discover their own bodies and desires in order to construct their own subjectivities.

Praxis then totally succumbs to Willie's whims and fancies. Although a better student than he is, she submits herself to Willie and prioritizes him over her. She deliberately works at making Willie academically better by securing him higher marks. She types Willie's essays before her own, thereby objectifying herself to patriarchy only to be a 'second sex.' So “after Willie's essays were completed and typed, she would then begin on her own” (108). Irma, as the voice of her superego, exclaims, "more fool you. It's war, you know. They lose and you win, or vice versa. It's vice versa for you” (108). Men like Willie refuse to accept that women can excel in education. In one instance, Praxis obtains an ' $A$ ' in one of her subjects while he scores a ' $C$ ' and his attitude towards her changes. Praxis "could not understand why he was so cross, or why he felt obliged to hurt her” (109). He even accused her of being “a neurotic, a bore, a rotten cook, and a slow typist” (109). Praxis's entire personality is gradually subsumed by Willie. He consumes her, to compel her total submission to him. Willie thus appears to be a real colonizer as he occupies Praxis's life and her space, taking advantage of her on many different levels - personal, sexual, academic and so forth. As such, Praxis succumbs to his absolute authority while Willie endeavors to nullify her existence. He assesses her as a "born housewife" 
and that "the taxpayer [is] wasting his money on you" (122). He discourages her academic ambition and explains that universities are not interested in housewives.

Willie denigrates and belittles Praxis's abilities, insinuating that the only job she is good at is nurturing others. He enslaves her completely, thus preventing her from taking any action that may liberate her. She is not allowed to question or object to anything but do his bidding, yet Willie describes her life as “one long holiday" (134). In order to compound her humiliation he makes her liable for her future to complete her degree. She soon becomes dissatisfied with her lot and starts to desire more out of life, but is unable to articulate her desire. Willie inquires about what she wants: "what, indeed. A man, a house, a child [baby Mary, adopted child]. It was what most women wanted" (136). This doctrine was then etched in stone, and women had to abide by this rule. Weldon has been critical of the sixties, seventies and eighties eras which objectified women. . Wives were not allowed to hold jobs, but were relegated to domestic roles that left no room for interaction with others. This eventually led them to become fully dependent on men who kept these women under their control. The narrator in Praxis declares that "[H]usbands had fought their way out of the world in which a working wife was a sign of family disaster, disgrace and humiliation" (203). For a woman to live freely, without any inhibitions, it meant going against the norm, as did Praxis who chose a life of prostitution. In the following excerpt, Praxis stresses the fact that males try to keep women down just like what Willie does to her:

Men, reflected Praxis, are commonly expected to marry someone poorer, less educated and of lower status than themselves. Women, likewise, are expected to marry above them. Thus every wife in the world will automatically feel in her domestic life and status, inferior to her husband. Because in fact she will be: and perhaps this way happiness and acceptance lies. The husband looking down. The wife looking up. (170)

Praxis mirrors a life of submissiveness, as did most married women then.. She reflects on how the English society constructs and interweaves its relations between men and women and how it excludes women's desires, identity and existence. What remains of them is only a submissive object that works on serving the male in every possible way.

In retrospect, Praxis wishes that she had reconsidered her life with Willie, voiced her opinions and thoughts, and done things differently. She confirms that she "was too nearly Willie's equal" and sometimes superior than him. But "he did his best: stopping my education, forbidding me to earn, reducing me to whoredom: yes, he certainly did his best” (170). This is how 
women suffer madness, hysteria and many other psychological distresses. Patriarchy ruled over and debased them so that they remained at the lowest rung of the social ladder. Praxis points out that "the question of partnership doesn't arise. The women do what they're told, and no one tries to change anything” (215). In this way, women's identity is wholly destroyed by patriarchy which ensures they remain non-subjective.

Praxis, with less education, insufficient options and money to support herself, then resorts to prostituting herself. Irma, Praxis's feminist friend, advises Praxis: "you sleep your way out" (142). Accompanied by her friend Elaine, Praxis goes to the Raffle Esplanade Dive pub where they meet some clients. The narrator confirms that Praxis and Elaine "were not prostitutes; just a couple of girls living life to the full, working their way out of difficulties, in a world which made any other solution impossible" (146) (Emphasis added). As such, prostitution to them is merely a means to an end. Praxis's character is similar to Firdaus's in El Saadawi's WPZ, who also resorts to prostitution when all other means fail. Under such harrowing circumstances, Praxis would rely on two Irigararian techniques to rescue what remains of herself. Mimicry and masquerade, as theorized by Irigaray, may help women regain part of their lost voice.

\section{Mimicry in Praxis}

Mimicry is, according to Irigaray, one of the means by which females can elevate their status. Irigaray confirms that mimicry is a path related to the feminine by which women assume the role of the feminine deliberately. They then convert the form of subordination to the male, into an affirmation of their identity (Irigaray 1985b, 76). Thus, the strategy of mimicry employed by Praxis, helps her to recover the place of her exploitation by discourse, "without allowing herself to be reduced to it" (1985b, 76). Mimicry can be juxtaposed to hysteria as both of these help women resist patriarchy. When Praxis performs mimicry, she then desires to continue and fit into the social pattern which is similar to the hysteric symptom that reveals the subject's resistance. When her existence is nullified by her family, Willie, and society in general, she then feels herself marginalized. She then employs mimicry which she considers as a feminist weapon that may help her regain her subjectivity in a male-centered society. She has been an obedient daughter, sister, and wife, and assumes her role as a serving object to every person she encounters without questioning her existence. By mimicking the male discourse, she assumes a role equivalent to that played by patriarchal males. Such a role may help to rid her of troubles and constitute her identity. Mimicking then becomes a desire to construct a discourse of power which is worn like a mask to hide and repress her true self which is perceived by others as an Other. 
The first step in mimicking the male discourse is to achieve financial independence. Ruth in the She-Devil manages to mimic the male discourse by achieving financial independence which consequently leads to subversion of her subjectivity, and removes any hysterical symptoms or signs of weaknesses she inherits from patriarchy. In a society that considers a working woman a disaster and advocates housewifery as in the case of Praxis, women are compelled to seek other sources of livelihood that weans off their dependence on men. Her first acts of mimicking lands her a career in prostitution which earns her some money because in patriarchal societies, money means power and whoever has money will also gain the upper hand. She is aware that being marginalized is ascribed to her being a consumer, not a producer. To her, prostitution is a way out of her troubles; it attributes some value to herself as she will be sought after by many males. In discussion with her friend Elaine about prostitution, Elaine confirms that asking for more money will not only elevate one's status but also add value to it:

Why was it better, Elaine asked, to give sexual services free, as she was often required to do? Didn't the exchange of money, as in psychoanalysis, raise rather than lower the value of the therapy offered? The more was charged, the more the client enjoyed himself. He had to. "It's like when you want to increase the sale of a lipstick, said Elaine, 'you don't lower its price, you double it. What you're selling is magic. (146)

Prostitution gives Praxis financial security and entry into the masculine discourse which owns the money/power. As far as patriarchy goes, it acts as a colonizer of women who are considered servants. Frederich Engels in his book The Origin of the Family had expounded that "the first premise for the emancipation of women is the reintroduction of the entire female into public industry" (2004, 80) which means that women also should be afforded egalitarian opportunities in a male dominated society.

Praxis mimics the male discourse through any possible means because she has tolerated enough suffering under Willie's rule. Her application for a job in BBC's research department is denied for her lack of qualifications. But she gets "a job on the reception desk because she was blonde, pretty, sensible and had an easy manner" (184) and starts to fend for herself. This step is a true mimicking process of the males which cannot be prevented by males. Praxis later gets the job she first applied for in the research department but which is disapproved by her husband-to-be, Ivor. But she persists and declares that "I'll do as I choose" (192). Mimicry as a technique is inherent in Praxis's choice of job as it elevates her to a job which is predominantly male. She is thus, contesting the status quo. Praxis then moves to work in the copy department "writing pamphlets for the 
electricity board" (229). She persists at her job and ensures that she is not controlled by any male. She is later promoted to copywriter and most agencies find her "a real discovery" while other agencies "tried to poach her" but she remained "loyal and got another rise" (231). Herein she becomes an active counterpart of males and thus gains self-respect and self-dependence.

\section{Masquerade}

In order to surpass male society and secure her existence in the Symbolic, Praxis employs Masquerade. As a technique it is complementary to mimicry which helps in restoring females' identity and removes any burden from femininity. Masquerade as such is a mask worn by women to preserve or attain subjectivity. According to Irigaray:

Masquerade to be understood as what women do in order to recuperate some element of desire, to participate in man's desire, but at the price of renouncing their own. In the masquerade, they submit to the dominant economy of desire in an attempt to remain 'on the market' in spite of everything. But they are there as objects for sexual enjoyment, not as those who enjoy. (1985b, 133-134)

Irigaray's viewpoint befits Praxis's status. One might argue that Praxis does not achieve independence from males or her husband, and had to fend for herself through prostitution to escape exploitation from others yet ends up being objectified. Similar to Firdaus in WPZ, Praxis surrenders her body to sex but withholds her feelings and desires because her foremost purpose is to gain financial independence to pursue her femininity as a subject. During sexual intercourse, while "her body [is] impaled" she "found her mind agreeably free to wonder" (105). Prostitution enables her to access the Symbolic order that governs her:

I was earning, after all; offering one of the few services the world allowed me to offer - apart, I suppose, from my dubious skills as a cleaner, or washerwoman, and I was doing that at home, anyway, unpaid [...] I was free to pick and choose my clients, and had time left over to look after home and child. (176)

This profession also enables her to regain part of her lost femininity which has been debased and degraded by males. She however, manages to recuperate her desire and embrace her femininity. She avers that she "was gaining some agreeable physical sensations" sometimes, and was able to "pick and choose my clients." (176) All of this meant that now, she had control over her body, her desire and men.. Hence only those who desired her could enjoy her body; she thereby vanquishes patriarchy and subdues its representatives to her control. 


\section{Conclusion}

Praxis starts by masquerading as a student and proves to be a smart student. She then has encountered Willie and Philip, both of whom destroy her prospects. When she starts to feel suffocated in a life beset with sorrow, she resorts to prostitution by which she eventually defines and establishes herself. Praxis has assumed many vocations since her early years; student, prostitute, copywriter, worker in the BBC, and an editor of a feminist newspaper. She then "wrote rousing editorials" (273). She joined the ranks of the Women's Movement and joined in sisterhood in a happier family than the world had ever witnessed. Praxis comes to conclude that she has to "cure the world to cure myself" (57). That is why she issues a clarion call to fight against nature because it is controlled by males. She asserts, "we [women] must fight nature tooth and claw" (158). She manages lastly to infiltrate the Symbolic world and becomes a subject equivalent to the male counterpart as she has achieved her independence and established herself as a free subject with a free voice.

\section{References:}

Engels, Frederick. (2004). The Origin of the Family, Private Property and the State. Australia: resistance Books.

Faulks, Lana. (1998). Fay Weldon. New York: Twayne Publishers.

Irigaray, Luce. (1985a). Speculum of the Other Woman. Ithaca, N.Y: Cornell University Press.

Irigaray, Luce. (1985b). This Sex Which Is Not One. Ithaca, N.Y: Cornell University Press.

Krouse, A. N. (1978). Feminism and Art in Fay Weldon's Novels. Critique: Studies in Contemporary Fiction, 20(2), 5-20.

Massie, Allan. (1990). The Novel Today: A Critical Guide to the British Novel, 1970-1989. London: Longman in association with the British Council. Print.

Showalter, Elaine. (1985). The Female Malady: Women, Madness, and English Culture, 1830-1980. New York: Pantheon Books.

Weldon, Fay. (1974). Female Friends. Chicago: Academy Chicago Publishers.

---. (1980). Praxis. London: Hodder and Stoughton. 